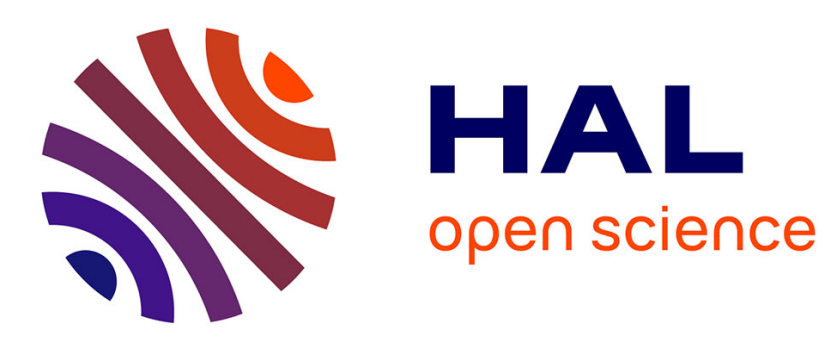

\title{
The role of antibodies in the light of the theory of evolution
}

\author{
Hélène Banoun
}

\section{To cite this version:}

Hélène Banoun. The role of antibodies in the light of the theory of evolution. African Journal of Biological Sciences, 2021, 3 (3), pp.1-9. 10.33472/AFJBS.3.3.2021.1-9 . hal-03311767

\section{HAL Id: hal-03311767 https://hal.science/hal-03311767}

Submitted on 2 Aug 2021

HAL is a multi-disciplinary open access archive for the deposit and dissemination of scientific research documents, whether they are published or not. The documents may come from teaching and research institutions in France or abroad, or from public or private research centers.
L'archive ouverte pluridisciplinaire HAL, est destinée au dépôt et à la diffusion de documents scientifiques de niveau recherche, publiés ou non, émanant des établissements d'enseignement et de recherche français ou étrangers, des laboratoires publics ou privés. 


\title{
A frican Journal of Biological Sciences
}

\author{
Journal homepage: http:/ / www.afjbs.com
}

Review Article

Open A ccess

\section{The role of antibodies in the light of the theory of evolution}

\author{
HélèneBanoun ${ }^{1 *}$ \\ 1Ph.D., Pharmacist Biologist, No affiliation (Former INSERM research fellow), Marseille, 13001, France +0033632647833. \\ E-mail: Helene.banoun@apostenet
}

\author{
Article Info \\ Volume 3, Issue 3, July 2021 \\ Received : 24 January 2021 \\ Accepted : 26 May 2021 \\ Published: 05 July 2021 \\ doi: $10.33472 /$ A FJBS.3.3.2021.1-9
}

\begin{abstract}
A bstract
The phenomenon of facilitation of viral infections by antibodies (ADE antibody dependent enhancement) as well as the resistance of agammaglobulinemia patients to certain viruses are in contradiction with the protective role of antibodies affirmed by classical immunology. This must be compared to the opsonizing antibodies that promote the specific phagocytosis of extra-cellular bacteria. However, questions about the role of antibodies have been raised since the beginning of the history of immunology. More recently, Pierre Sonigo has shed light on the contradictions between the finalist interpretation of the role of lymphocytes and the theory of evolution: how can it be explained that cells are selected to protect the organism they constitute? The role of anti-viral and antiintracellular bacteria antibodies could be to allow phagocytosis by the cells: either directly by the Fc fragment of immunoglobulins, or via the complement for many cell types. This makes it easy to understand the selection of antibodysecreting cells. Natural selection favors the cells that produce the most affine Ig and thus guides the maturation of the proB cell to the plasma cell. A review of recent publications in theoretical immunology is consistent with this hypothesis. The theory of evolution should be integrated at every level of research and teaching in immunology, as it is for biology as a whole.
\end{abstract}

Keyw ords: Immunology, Evolution, A ntibodies, Virology

C 2021 HélèneBanoun. Thisisan open accessarticleunder the CC BY license (https:/ / creativecommons.org/ licenses/ by/ 4.0/ ), which permits unrestricted use, distribution, and reproduction in any medium, provided you give appropriate credit to the original author(s) and thesource, providealink to theCreativeCommonslicense, and indicateif changes weremade.

\section{Introduction}

Thephenomenon of antibody facilitation of viral infections has recently been re-discussed in relation to the clinical aspect of Covid-19 (Yushun et al., 2020 and Banoun, 2020) and vaccines against this infection (Roper and Rehm, 2009). A ntibody dependent enhancement is theaccepted mechanism to explain severereinfections dueto denguevirus-among others-(Taylor et al., 2015) as well as thehigher occurrence of severedenguein vaccinated (compared to unvaccinated, Feinberg and A hmed, 2017).

This effect of antibodies appears to contradict immunological theory, which states that the "role" of antibodies is to protect organisms against pathogens, including viruses.

However, contradictory observations havelong been noted.

A Iready in 1956, a review was published (Good and Zak, 1956) which referred to “theclinical paradox posed by the apparently satisfactory resistance of patients with agammagl obulinemia to certain viral infections and thefailure

* Corresponding author: Hélène Banoun, Ph.D., Pharmacist Biologist, No affiliation (retired), M arseille, 13001, France +0033632647833. E-mail: H elene.banoun@laposte.net

2663-2187/ @ 2021 Hélène Banoun. This is an open access article distributed under the Creative Commons Attribution License,which permits unrestricted use, distribution, and reproduction in any medium, provided the original work is properly cited. 
of their responseto thevirus antigen....". A snoted by Burnet (1968), measles immunity is independent of antibodies, but depends solely on cellular immunity. Thesamedemonstration has recently been made for immunity to VSV (vesicular stomatitis virus, M oseman et al., 2012).

These observations have been reviewed by Sanna and Burton (2000). They arecriticized becauseall patients diagnosed wuth ayglobulinemia would have received IM immunoglobulin as early as the early 1950s, and thus thecompletenull phenotype has been littlestudied. Theauthors suggest that thetreatment given to these patients indicates that antibodies may play a role in viral infections. Some viral infections that these patients developed before treatment virtually disappeared after theinitiation of treatment. However, it cannot bedenied that the arglobulinemia patients were discovered by the bacterial infections they developed and not by the viral infections.

It appears that humoral immunity plays a rolein HSV (H erpes simplex virus, neurologically disseminated enterovirus) infections for viruses with nervous tropism and for persistent viral infections.

Moreover, it is difficult to attribute the discovery of an infection in an antibody deficient patient to a particular virus: the serological diagnosisis inoperative; it was necessary to wait for the culture of theviruses and especially the PCR to affirm a viral infection.

Therefore, this last publication does not call into question thefirst observations on argl obulinemia patients: patients are very sensitive to bacterial infections and for the majority of viral infections, their sensitivity is comparableto that of the general population.

Much more recently, the pandemic at Covid-19 has mobilized thousands of researchers and allowed significant advances in immunology and virology. Onestudy compared serologies and cell typeimmunity in Covid-19index patients and their contacts: only index patients becameseropositive, but both groups showed robust and specific cell typereactivity to SA RS-CoV-2 (thevirus responsiblefor Covid-19) (Gallais et al ., 2020).

Similarly Sekine et al. (2020) showed that most individuals with asymptomatic or moderate Covid-19 generated highly functional durable memory $\mathrm{T}$-cell responses in the absence of a corresponding humoral response.

Therole of antibodies in bacterial infections is well established in the defenseagainst extracellular bacterial infections (as opposed to intracellular infections) (Berche, 1988). The frequency of infections in patients with genetic abnormalities of phagocytes is indicative of theimportance of phagocytosis.

Bacteria, once phagocytized, are degraded and then exocytosed, making theantigens accessibleto thecells of adaptiveimmunity. The antibodies then act by promoting phagocytosis, which is the natural process of fighting pathogenic bacteria: they are opsonizing antibodies, another term for facilitators. Could the neutralization and agglutination of bacteria observed in vitro not occur in vivo?

Complement (agroup of serum proteins) plays an important rolein phagocytosis. Theseproteins act on the one hand by binding to specific antibodies, but complement is also activated by the alternating pathway induced directly by surface bacterial antigens: lipopolysaccarides, capsule polyosides, lipotechoic acids, and this in the absence of antibodies.

However, as with viral infections, the first line of defenseis innateimmunity: during a primary infection it takes 7 to 10 days to mount a specific humoral reaction, and it is non-specific phagocytosis that operates first. A good example is pneumococcal pneumonia. Pneumococcus is a commensal upper airway bacterium that becomes pathogenic when it acquires a phagocytosis-resistant capsule. In young adults the evolution is typical: after incubation of 1 to 3 days, a sudden onset, high fever, cough, theevolution is favorablein 8-10 days with a sudden improvement. This improvement corresponds to the appearance of specific antibodies. The inflammatory (polynuclear) reaction ai ded by theopsonizing specific antibodies will destroy thepneumococci and lead to healing.

H ow can this opsonizing roleof antibacterial antibodies berelated to the phenomenon of the facilitation of viral infections by theantibodies?

PierreSonigo, oneof the discoverers of theAIDSvirus in the1980s, reflected on thetheory of immunology and the problems it poses in relation to thetheory of evolution (Kupiec and Sonigo, 2003).

Before giving a brief summary of his theses, a historical overview of this science can account for the theoretical gaps that accompanied its birth. 


\section{History}

Immunology is commonly defined as the science that studies the defense systems of living organisms against external aggressions. These systems exist from the origin of life and have evolved of course with it (Rascol et al., 2007).

Immunological science first developed as a simple commentary on vaccination techniques, discovered empirically. Phagocytosis, discovered in 1883, was left asidein favour of thein vitro study of humoral immunity - antigen-antibody interaction after chemical purification (M oulin, 1983).

The term immunological "system" is problematic because it implies finalism and invariance, which is al ready incoherent with Darwinism. Wesee a system because we attributeto it theroleof protecting us. The system would be matureat a certain age in children, and it would bea given until senescence, when it would collapse (Valletet al., 2019). But immunity refers to both a process and a result: the process is the one by which the organism defends itself against an infectious disease, and the result is the ability to resist reinfection against the same pathogen. Theprocess is in constant evolution in relation to theenvironment: theimmunity of thenewborn is built up in relation to themicrobiota it encounters at birth. This process is activethroughout lifein responseto themicrobiota and external pathogens: it is aco-evolution of themicrobiota and thehost's 'immune' cells (Pirofski and Casadevall, 2012).

The methodological reductionism essential to the practice of science has led to the distinction between cellular and humoral immunity.

Thetheory of cellular immunity has long sincefallen into thebackground; theemphasisfrom the beginning, as mentioned above, has been on serology, which is, moreover, theformer name of thespecialty in France: the study of solublefactors that can be easily isolated from serum from blood. N owadays serology has an additional advantageover cellular immunity: it is easily automated and can integratean industrial process. Conversely, individualized study of cellular immunity for different patients is not yet possible. However, itisnow accepted that the two processes are closely intertwined: the cells of theimmunesystem interact with each other through numerous molecules that they secrete and absorb.

Where do the terms antigen and antibody comefrom?

"The term antigen appears for the first time in the annals of the Institut Pasteur. It enters everyday language as quickly as theterm antibody. Theword gene, commonly used at that timeby many biologists, did not refer to genetics. It corresponds to theidea that the antigen establishes a relationship with theantibody, or rather modifies it. M oreover, the definition remains very circular, theantigen inducing theantibody and viceversa. O necharacterizes theother in a perfect tautology: the antibody is theone that recognizes theantigen “(Debréand Gonzales, 2013). Moreover, the AngloSaxons felt the need to invent a falseetymology for the term antigen: "antibody generator"! (Wikipedia, 2016).

"At the time of Behring and R oux, thenature of antibodies was unknown, but their roleseemed clear: to defend the body. Then this rolewas questioned. The complement-fixing antibody is cytotoxic for theattacker and sometimes al so for thehost. It can facilitateand protect thegraft " (Moulin, 1983).

Thesequestions about theroleof antibodies seem to beforgotten nowadays, although they are coming back to thesurface of the debatefollowing the "paradoxical" observations of theantibody dependent enhancement.

\section{Pierre Sonigo's evolutionary vision}

Jean-Jacques Kupiec and Pierre Sonigo propose to refer to the theory of evolution by applying it at thecellular level (Kupiec and Sonigo, 2003):

“Thecells that composeus livefor them, not for us. Thetheory of evolution, which predicts the emergence of equilibria by variation and selection, not by a prior plan, is not applied by biologists at thecellular or molecular level. Immunology is built on a curious mixture of the D arwinian model of random selection (which helps explain antibody synthesis) and specificity in molecular biology. Specificity is a fixist concept that does not fit well with evolution. In this respect immunology is exemplary of thesplit in modern biology between thetheory of evolution and genetic determinism. The theory of clonal selection of antibody synthesis is not compatiblewith thetheory of evolution, although it does contain the alternation of chanceand selection."

(This is thetheory of Jerne(1955), Burnet (1957) Nature (2007), according to which information pre-exists in thecell. Theexternal environment intervenes only at the level of the selection of cell clones, to amplify an 
existing response. Tonegawa (1983) explains how recombinations and mutations in lymphocytegenes increase the diversity of variablechains of synthesized immunoglobulins).

"But selection is conceived as a signal, and the signal is an order, not a selective advantage in itself. The ben efit obtained does not benefit the cell but the entire organism: this changein the object of selection is problematic. $\mathrm{N}$ atural sel ection cannot retain a program that is only a virtual, unreal ized representation of a function. Thelymphocyte that has thebest antibody (which attaches best to theantigen) multiplies because it has captured the resources that allow it to do so" (Kupiec and Sonigo, 2003).

\section{A bout the role of antibodies in viral infections}

Let's apply this same reasoning to the "paradoxical" phenomenon of antibody dependent enhancement of viral infections. P Sonigo's remark about AIDS virus research can be applied to thestudy of antibodies:

"D escriptions of thevirus at the mol ecular level arebecoming moreand more detailed. Thecomplexity of the virus is becoming clearer and clearer.... If what wediscover is increasingly complex, isn't this progress theopposite of a science that is supposed to shed light and not elaborate on complexity?" (Kupiec and Sonigo, 2003).

This complexification can befound, for example, in thestudy of plasma cells (Burjanadzeet al ., 2009).

Pierre Sonigo brought together the two fields of immunology (humoral and cellular) in his evolutionary vision.

It is a question here of specifying what his demonstration implies, particularly in serology (in thefield of humoral immunity).

We can resume the demonstration of $\mathrm{P}$ Sonigo by qualifying the antibody (immunoglobulin) as a hook allowing the cell to capture its food, whether it is a soluble or particulate antigen presenting antigens on its surface (bacteria, viruses, ...). Historically, the antigen-antibody interaction has been studied in vitro, in a salineenvironment far from thenatural environment insidean organism. Similarly, theinteractions of antibodies or viruses with cultured cells are studied in a saline medium (see on this subject Cunchillos, 2014, in the chapter on enzymatic reactions, why the kinetics of the reactions observed in vitro cannot be transposed to what happens in vivo, and also Kupiec, 2019). "Theforces that uniteantibodiesto haptens arenot fundamentally different from those governing the different interactions between proteins or between enzymes and substrates" (Chatenoud and Bach, 2012).

The agglutination power of antibodies to particulate antigens is observed in vitro: this power is used in serology to quantify the presenceof antibodies in a serum. The ability of certain antibodies to neutralizethe activity of a virus or bacterium is also observed in vitro. For example, in a cultureof virus-sensitive cells, a virus can be prevented from entering thetarget cells by adding an antibody to thevirusin theculturemedium.

From this, it was inferred that these antibodies werealso agglutinating or neutralizing in vivo. Could the neutralization and agglutination observed in vitro not occur in vivo? From an evolutionary point of view, what would bethe "interest" for plasma cells to secreteantibodies to agglutinateor neutralizean antigen or virus? If this interaction is not followed by phagocytosis? How could these plasma cells be selected? If, on the contrary, theantibodies, in vivo, do not agglutinateor neutralizeanything, butallow the plasma cell to capture theantigen, everything becomessimple! The "role" of theantibody then becomes that of allowing phagocytosis by the cells. The B cell line is the one that gives rise to plasma cells, the "antibody factories" (Batista, 2017). How can this frenzy of immunoglobulin production be explained from an evolutionary point of view other than by the supposed need to protect theorganism that harbors them fromaggressors?

Immunoglobulins (Ig) are proteins present in membraneform (BCR, B cell receptor) and in solubleform (antibodies): the merefact that these I garenamed in two different ways depending on whether they are present in membraneform or in solubleform is indicative of theepistemological obstacleto understanding their role. These BCRs are internalized and allow the capture and subsequent digestion of the antigen by the B cell. This is "unexpected" for the authors of one study (taken at random but significant, Pinto et al., 2013). The affinity of this BCR for the antigen obviously plays a key rolein the differentiation and proliferation of B cells (Yam-Puc et al., 2018). Yet it has long been known that the Fc fragment of IgG is essential for antibody immunosuppression, al though theFab fragment binds morestrongly to theantigen compared to completelgG (Chan and Sinclair, 1971). 
Moreover, it is difficult to find publications highlighting thestructure of BCRs according to the stage of $\mathrm{B}$ cell differentiation. In particular, scientists aremore interested in the non-specific and membrane-bound part (thecytoplasmic tail) of thelg that makes up theBCR: they seek to identify thesignals that would trigger the modification of the B cell's gene expression once it has picked up theantigen on its surface (Xu et al ., 2014).

Thesesamescientists are much less interested in the specific Fab part of the antigen and its internalization: how does this captureand digestion of theantigen influencegeneexpression? They go so far as to besurprised thatchanges in geneexpression profiles are shared between memory B cells, memory $T$ cells and hematopoietic stem cells, suggesting a non-specific mechanism of differentiation under theaction of "transcription factors" (Kupiec, 2019). In a figure from a review concerning the regulation of B cell development, the antigen is moreover forgotten: only the antibody produced by thecells is supposed to intervenein the maturation of the lineage (Shapiro-Shelef and Calame, 2005).

It is easy to get lost in the jungle of studies that seek to identify in an increasingly complex manner the intracellular "signals" activated by theinternalization of theBCR attached to theantigen; theauthors of these publications seem to forget that theBCR is made up of thesamel $g$ that is al so secreted by the plasma cell, and that the internalization of the BCR-Ag complex is followed by the digestion of the antigen. However, this information is found in textbooks (A l berts et al., 2002). Yet, as Chomin Cunchillos explains, if the teaching of biology werebased on thetheory of evolution, it would beso much simpler to explain B cell differentiation and proliferation on this basis!

All Ig classes are represented in BCR, not only IgA and IgM, always obviously according to the stage of differentiation (Xu et al., 2014). The cells of theB lineageare, at all stages of maturation, capable of capturing IgA g complexes and feeding on them. Thegreater theaffinity of thelg they secretefor Ag, themore efficient the capture of resources and the more they proliferate; natural selection favors the cells that produce the most affine I $g$ and thus guides the maturation from the proB cell to the plasma cell. If one can translate, all this is clearly stated in publications that try to explain why and how B lineagecells differentiate, mature, proliferate and synthesize large amounts of antigens. It is all in the vocabulary that wejust have to change: instead of transformation of the antigen oncecaptured by thecell, we should read digestion, instead of presentation of theantigen on thecell surface, we should read rejection of thewaste products of digestion captured by other cells that revel in it:

"The antigen, thestarting resource, is phagocyted and digested by a first kind of immune cells that regurgitate the metabol ites resulting from this digestion. 0 ther kinds of cells will feed on this waste. A mong thesewastes wefind what are called cytokines which arethefeast of certain cells whose proliferation they allow. Rather than assuming the existence of cascading signals for regulation and metabolism, it is sufficient to consider a singlechain of transformation: the binding of the molecule to thecell membrane, its penetration and then thesteps of its metabolic treatment in continuity. A cytokine (with non-specific effect) will inducetheproliferation of a largepopulation of lymphocytes; an antigen will only influence a small number of very specialized clones" (Kupiec and Sonigo, 2003).

This metabolic chain expresses thecooperation between cells (another constant of biological evolution that Darwin insisted on): cells stabilize in a given typeaccording to the interactions they can establish with their environment; they are ableto usein an optimal way theavailableresources, whether, here, native antigens or thewaste products of thedigestion of antigens by other cells (Kupiec, 2019).

How do memory plasma cellsfeed when thereis no moreantigen? They takerefugein places wherenonspecific "growth factors" arequiteabundant: in the bonemarrow germination centers (Farhi, 1989) (wehumans also enjoy this nutrient-rich bonemarrow!). These growth factors arenaturally food for cells of all kinds.

But the countless antigens that an organism encounters arenutrients that many cell types covet. Thereis intense competition for immunoglobul in-fixed antigens, not only betwen plasma cell lines but also with other cell types.

Plasma cells, NK cells, macrophages and many other less "specialized" cells have receptors for the Fc fragment of immunoglobulins (this fragment is the non-specific part of themoleculethat does not bind to the antigen). I will not discuss here the term "receptor" and what it implies about the specificity of molecular interactions (Kupiec, 2019; and Cunchillos, 2014). This "receptor" is a protein that interacts preferentially with Ig Fc and then allows the internalization of the Ig-Ag complex that will be digested by the cell. As mentioned above, many immunecells haveFcreceptors, but for many cell types thereis another way to capture this resource: complement fixation. Complement is a set of proteins, themain one being C1Q, which has a high 
affinity for the Fc fragment of Ig. Endothelial cells, fibroblasts, among others, possess receptors for this C1Q and are capable of capturing antigens by this means (Fonseca et al., 2001). It has been shown that this pathway facilitates certain viral infections (for theEbola virus, for some Parvoviruses, Von Kietzell et al ., 2014).

TheseFcRs play an important role in facilitating non-viral infections in autoimmunediseases. For tumors, this FcR may have a role in reducing metastasis by anti-tumor antibodies (Ravetch and Bolland, 2001). Conversely, theimmunological facilitation of tumors could be interpreted in thesame way. When miceare immunized agai nst theantigens of their tumors, tumors may develop faster in immunized animals (Vivier and Daëron, 2018): aretumor cells abl eto captureantibodies directed against their surfaceantigens, theseantibodies then becoming their food, which explains their proliferation?

Despite the lack of purpose of their production, antibodies can however play a protective role in viral reinfections and are necessary for defense against extracellular bacterial infections: it should therefore be explained why antibody facilitation is not always observed in viral infections. It has obviously not been researched, but it has sometimes been imposed because it is too visible, as in thecaseof influenza, denguefever or coronavirus infections (a complete review has been published on antibody facilitation of viral infections, Taylor et al., 2015).

It can beassumed that, in general, innate antiviral immunity eliminates most attackers beforeantibodies aresynthesized sufficiently to facilitateinfection (Fafi-Kremer, 2020). It has recently been shown that immunity to VSV (vesicular stomatitis virus) is independent of antibodies, but depends solely on cellular immunity. B lymphocytes are thought to play a non-specific role in stimulating T cells: they secrete a "Iymphotoxin" capable of activating macrophages, which then become capable of secreting Interferon 1; this "Iymphotoxin" can beinterpreted as food for themacrophage and is thought to induceits proliferation.

The quantity and affinity of theantibodies produced areimportant to consider. Solubleantibodies secreted in excess by plasma cells represent a nutritiveresourcefor many cell types that could capturethem before they can induce facilitation. Indeed this facilitation occurs for certain serum antibody levels and for low affinity antibodies, so not in all circumstances: this has been shown for denguere-infections (Katzelnick et al., 2017).

There is no question here of delving into the details of Pierre Sonigo's vision, this time applying it to adaptivecellular immunity: it would beinteresting to investigatetheroleof competition between cells for the capture of antigenic resources. T Cell Receptors (TCR) arein fact al so membraneimmunoglobulins and are "encoded" by genes similar to those that codefor antibodies (Britannica et al., 2020). They recognizeantigenic fragments of pathogens partially digested by infected cells: these fragments could be interpreted as waste products rejected by thesecells.

In a review, Kaspenberg (2003) underlines therole of theantigen doseand the affinity of TCR receptors for it in theorientation of T cell differentiation (towards theTh1, Th2, Treg pathways): competition between cells for thenutrient resourcewould bethekey to differentiation and proliferation.

\section{Conclusion}

A ntibodies play a central rolein the fight against extracellular bacterial infections and may play a significant rolein viral reinfections. Conversely, in intracellular viral and bacterial infections their rolemay belimited to facilitating infection. A common characteristic of intracellular viruses and bacteria is that they divide within thecell, unlike extracellular bacteria.

During bacterial membrane synthesis and division, it can be assumed that the accessibility of bacterial membraneantigens is modified. A ntibodies could be secreted in large quantities and with a strong affinity only agai nst theantigens of extracel lular bacteria: bacterial division in theextracellular medium would release a large quantity of bacterial antigens capable of proliferating increasingly specific plasma cells. Theantigens of intracellular bacteria would beexcreted only after division in the cell and antibodies directed against them would not beableto hinder bacterial division. Antibodies would play a protectiveroleonly againstextracel lular bacteria because they would act at the time of division, when antigens are more accessible and in greater quantity.

Concerning viral infections, therecent Covid epidemic has led to advances in the understanding of therole of antibodies. They are often not synthesized in benign or asymptomatic infections (Gallais et al ., 2020), when cellular immunity is activated. It is therefore possiblethat, as suggested by theauthors and al so by another study on thecellularT responseto Covid (LeBertet al., 2020), theinnateresponsemay abort full viral replication, 
asthesmall amount of accessibleviral antigens is not sufficient to inducea humoral response. However, the low level of viral replication in these poorly or asymptomatically active patients would besufficient to activate a robust cellular response. The role of antibodies in Covid-19 has been evoked in the immunopathological phenomena characteristic of this disease (Banoun, 2020): severe infections areassociated with high antibody levels compared to those of moderateinfections.

With regard to bacterial infections, thephenomenon of immunetoleranceshould betested by thetheory of evolution. Indeed, most extracellular pathogenic bacteria are commensal bacteria that become pathogenic under certain circumstances (modification of theflora, mucous membranes, immunestatus of thecarrier, ...): in normal times they do not causeinfection, do they cause the synthesis of antibodies directed against them?

If so, why do theseantibodies not act?

If not, this phenomenon of immune tolerance can be explained by theformation of the immune system according to themicrobiota that develops at birth. Classically, theapoptosis of lymphocytes reactiveto "self" antigens and commensal bacteria is used to explain this tolerance. A poptosis is not compatiblewith thetheory of evolution: how would cells that "commit suicide" beselected? Themechanism by which negative selection can lead to the elimination of $\mathrm{B}$ cells that react to autoantigens is not elucidated (clonal deletion or receptor editing) (Nemazee, 2017).

According to Eric Vivier, professor of immunology, "The immune response is always induced by a discontinuity that is not only qualitative. The important thing is change and its rapidity. What makes an antigen is a variation in quality over time and a difference in quantity. The microbial world controls our immunesystem as much as theopposite" (Vivier and Daëron, 2018).

Is it possibleto reinterpret thework of thousands of researchers and theresults of thousands of publications?

How can immunology research bereoriented in an evolutionary direction?

Is it possibleto abandon the idea that antibodies do not al ways havea protective role, but that in certain cases (acute viral infections, intracellular bacterial infections) they are simple witnesses of an encounter with a pathogen?

How can the theory of evolution beintegrated at each level of biology teaching and not just as a separate field? Teaching immunology starting with the immune defenses of thefirst organisms (bacteria) could make this scienceeasier to explain: innateimmunity may havepreceded adaptiveimmunity and should thereforebe mentioned first (Tsakou-N gouafo et al ., 2020): “A complex innatei mmunesystem may haveexisted long before theemergence of the vertebrateancestor. This may have included largemultigenefamilies able to recognize foreign pathogens, cell proliferation and immunememory following pathogen contact....". Pathogen recognition is believed to be mediated by non-specific receptors capable of binding to the PAMP (Pathogen-associated molecular pattern) motifs of pathogens.

\section{Funding}

No funding sources

\section{References}

Alberts, B., Johnson, A., Lewis, J., Raff, M., Roberts, K. and Walter, P. (2002). M ol ecular Biology of the Cell . $4^{\text {th }}$ edition. N ew York, Garland Science, Id., BCellsand A ntibodies. https:/ / www.ncbi.nlm.nih.gov/ books/ NBK26884/

Banoun, H. (2020). COVID 19: Cross-I mmunity with Other Coronaviruses, I mmunopathol ogical Phenomena. https:/ / dx.doi.org/ 10.2139/ ssrn.3654264

Batista, F. (2017). in Genetic enginering and biotechnologies news, Antibody Factory in a Dish https:/ / www.genengnews.com/ topics/ drug-discovery/ antibody-factory-in-a-dish/

Berche, P., Gaillard, J.L. and Simonet, M. (1988). Bacteì riologie: bactéries des infections humaines. Paris: Flammarion meidecine-sciences. ISBN 2257104897.

Britannica, Perdue, S.S. and Humphrey, J.H. (2020). Immune system. Encyclopædia Britannica. https:/ / www. britannica.com/ science/ immune-system 
Burjanadze, M., Roosnek, E., Passweg, J. and Huard, B. (2009). A PRI L fait le printemps des plasmocytes. M ed Sci (Paris). 25(1), 5-8. https:/ / doi.org/ 10.1051/ medsci/ 20092515

Burnet, F.M . (1968). M easles as an index of immunological function. Lancet. September 14, 2(7568), 610-613. https:/ / doi.org/ 10.1016/ S0140-6736(68)90701-0

Chan, P.L. and Sinclair, N.R. (1971). Regulation of theimmuneresponse. V. An analysis of the function of the Fc portion of antibody in suppression of an immuneresponsewith respect to interaction with components of the lymphoid system. I mmunology. 21(6), 967-981.

Chatenoud, L. and Bach, J.F. (2012). M sp, Collection : Dela biologieal la clinique (6th edition) Paris: Lavoisier.

Cunchillos C. (2014). Les voies del'èmergence, I ntroduction aì la théorie des unitès de niveau d'inteigration. Paris, Belin.

Debreì, P. and Gonzales, J.P. (2013). Vie et mort des eìpideìmies, Paris : Odile Jacob, EAN : 9782738129734

Fafi-Kremer, S. (2020). I nterview in M edscape, I mmunitécontrele Covid-19: que sait-on à cestade? https:/ / francais.medscape.com/ voirarticle/ 3606141?nlid=136357_2401\&src=W N L_md plsnews_200 713 MSCPEDIT_FR\&uac=244220A Y\&faf=1

Farhi, D.C. (1989). Germinal centers in thebonemarrow. H ematol Pathol. 3(3), 133-6. PMID: 2592293.

Feinberg, M.B. and A hmed, R. (2017). A dvancing denguevaccine development. Science. 358(6365), 865-866. https:/ / doi:10.1126/ science.aaq0215

Fonseca, M .I., Carpenter, P.M., Park, M., Palmarini, G., Nelson, E.L. and Tenner, A.J. (2001). C1qRp, a myel oid cell receptor in blood, is pred ominantly expressed on endothelial cell s in human tissue. J ournal of Leukocyte Biology, 70(5), 793-800. https:/ / doi.org/ 10.1189/ jlb.70.5.793

GallaisF., Velay, A., Wendling, M.J., Nazon, C., Partisani, M., Sibilia, J., Candon, S. and Fafi-Kremer, S. (2021). Intrafamilial Exposure to SARS-CoV-2 Associated with Cellular Immune Response without Seroconversion, France. Emerg Infect D is. 27(1), 113-121. https:/ / dx.doi.org/ 10.3201/ eid2701.203611

Good, R.A . and Zak, S.J. (1956). Disturbances in gammaglobulin synthesis as experiments of the nature. Pediatrics. 18(1), 109-149. https:/ / pediatrics.aappublications.org/ content/ pediatrics/ 18/ 1/ 109.full.pdf

Kapsenberg, M. (2003). Dendritic-cell control of pathogen-driven T-cell polarization. N at Rev Immunol. 3, 984-993 (2003). https:/ / doi.org/ 10.1038/ nri1246

Katzelnick, L.C., Gresh, L., H alloran, M .E., Mercado, J.C., Kuan, G., Gordon, A., Balsameda, A. and Harris, E. (2017). Antibody-dependent enhancement of severe dengue disease in humans. Science. 358(6365), 929-932. http:/ / doi:10.1126/ science.aan6836

Kupiec, J.J. and Sonigo, P. (2003). Ni Dieu ni geÌne, Pour une autre théorie de l'heìreìdité. Paris : Seuil.

Kupiec,J.J. (2019). Et si levivant était anarchique, La geìneìtiqueest-elleunegigantesquearnaque? Paris: Les liens qui libel rent. ISBN : 979-10-209-0793-6

LeBert, N., Tan, A.T., Kunasegaran, K., Tham,C., Morteza, H., Chia, A., Hui Yen Chng, M., Lin, M., Tan, N., Linster, M., Chia, W., Chen, M.I.C., Wang, L.F., Ooi, E.E., Kalimuddin, S. Tambyah, P.A., Guek-Hong Low, J., Tan, Y.J and Bertoletti, A. (2020). SARS-CoV-2-specific T cell immunity in cases of COVID-19and SARS, and uninfected controls. N ature 584, 457-462 https:/ / doi.org/ 10.1038/ s41586-020-2550-z

Moseman, E.A., Iannacone, M., Bosurgi, L., Tonti, E., Chevrier, N., Tumanov, A., Fu, Y.X., Hacohen, N . and Von Hadrian, U.H. (2012). B cell maintenance of subcapsular sinus macrophages protects against a fatal viral infection independent of adaptive immunity. Immunity. 36(3),415-426. https:/ / doi:10.1016/ j.immuni.2012.01.013

Moulin, A.M . (1983). Del'analyseau systel me: le dèveloppement del'I mmunologie. In: Revued'histoiredes sciences 36(1), 49-67. https:/ / doi.org/ 10.3406/ rhs.1983.1903

Nature(2007). Sir Frank M acfarlane Burnet 1899-1985. N at Immu nol. 8, 1009. https:/ / doi.org/ 10.1038/ ni10071009

Nemazee, D. (2017). Mechanisms of central tolerance for B cells. N at Rev Immunol. 17(5),281-294. https:/ / doi:10.1038/ nri.2017.19

Pinto, D., Montani, E., Bolli, M., Garavaglia, G., Sallusto, F., Lanzavecchia, A. and Jarrossay, D. (2013). A functional BCR in human IgA and IgM plasmacells. Blood May 16, 121(20), 4110-4114. https:/ / doi.org/ 10.1182/ blood-2012-09-459289 . 
Pirofski, L.A. and Casadevall, A. (2012). Q\&A : What is a pathogen? A question that begs the point. BM C Biololy. 10, 6. https:/ / doi.org/ 10.1186/ 1741-7007-10-6

Rascol, V.L., Pontarotti, P. and Levasseur, A. (2007). A ncestral animal genomes reconstruction. Curr 0 pin Immunol. 19(5), 542-546. https:/ / doi.org/ 10.1016/ j.coi.2007.06.009

Ravetch, J.V. and Bolland, S. (2001). IgG Fc receptors. A nnu Rev Immunol . 19, 275-290. https:/ / doi.org/ 10.1146/ annurev.immunol.19.1.275

Roper, R.L. and Rehm, K.E. (2009). SA RS vaccines: wherearewe?. Expert Rev V accines. 8(7), 887-898. https:/ / doi.org/ 10.1586/ erv.09.43

Sanna, P.P. and Burton, D.R. (2000). Roleof antibodies in controlling viral disease: lessons from experiments of nature and gene knockouts. Journal of Virology. 74(21), 9813-9817. https:/ / doi.org/ 10.1128/ jvi.74.21.9813-9817.2000

Sekine, T., Perez-Potti, A ., Rivera-Ballesteros, O., Stralin, K., Gorin, J.B., Olsson, A., Llewellyn-Lacey, S., Kamal, H., Bogdanovic, G., M uschiol, S., Wullimann, D.J., Kammann, T., Emgard, J., Parrot, T., Folkesson, E., Karolinska COVID-19Study Group, Rooyackers, O., Eriksson, L.I., Henter, J.I., Sonnerborg, A., Allander, T., A lbert, J., N ielsen, M., Klingstrom, J., Gredmark-Russ, S., Bjorkstrom, N .K., Sandberg, J.K., Price, D.A., Ljunggren, H.G., Aleman, S. and Buggert, M. (2020). Robustt cell immunity in convalescent individuals with asymptomatic or mild covid-19. Cell. 183(1), 158-168. e14. https:/ / doi.org/ 10.1016/ j.cell.2020.08.017

Shapiro-Shelef, M . and Calame, K. (2005). Regulation of plasma-cell development. N at Rev Immunol. 5(3), 23042. https:/ / doi.org/ 10.1038/ nri1572

Taylor, A., Foo, S. S., Bruzzone, R., Vu Dinh, L., King, N.J.C. and Mahalingam, S. (2015). Fc receptors in antibody dependent enhancement of viral infections. Immunol Rev. 268(1), 340-364. https:/ / doi.org/ 10.1111/ imr.12367

Tonegawa, S. (1983). Somatic generation of antibody diversity. N ature. 302(5909), 575-581. https:/ / doi.org/ 10.1038/302575a0

Tsakou-N gouafo, L., Paganini , ., Kaufman, J. and Pontarotti, P. (2020). Origins of the RA G transposomeand theM HC. Trends I mmunol. 41(7),561-571. https:/ / doi.org/ 10.1016/ j.it.2020.05.002

Vallet, H., Fali, T. and Sauce, D. (2019). Le vieillissement du systel̀ me immunitaire : du fondamental al la clinique[A ging of theimmunesystem: From fundamental to clinical data]. Rev M ed Interne. 40(2),105111. https:/ / doi.org/ 10.1016/ j.revmed.2018.07.005

Vivier, E. and Daeron, M. (2018). L'Immunotheirapied es cancers Histoire d'une rèv volution meì dicale. Paris: OdileJacob.

von Kietzell, K., Pozzuto, T., Heilbronn, R., Grossl, T., Fechner, H. and Weger, S. (2014). A ntibody-mediated enhancement of parvovirus B19 uptake into end othelial cells mediated by a receptor for complement factor C1q. J V irol. 88(14), 8102-8115. https:/ / doi.org/ 10.1128/ jvi.00649-14

Wikipedia(2016). https:/ / en.wikipedia.org/ wiki/ 2016

Xu, Y., Xu, L., Zhao, M ., Xu, C., Fan, Y., Pierce, S.K. and Liu, W. (2014). N o receptor stands al one: IgG B-cell receptor intrinsic and extrinsic mechanisms contribute to antibody memory. Cell Res. 24(6),651- 664. https:/ / doi.org/ 10.1038/ cr.2014.65

Yushun, W., Shang, J., Sun, S., Tai, W., Chen, J., Geng, Q., He, L., Chen, Y., Wu, J., Shi, Z., Zhou, Y., Du, L. and Li, F. (2020). M olecular mechanism for antibody-depend ent enhancement of coronavirus entry. J ournal of Virology. 94(5), e02015-19. https:// doi.org/10.1128/jvi.02015-19.

Yam-Puc, J.C., Zhang, L., Zhang, Y. and Toellner, K.M . (2018). Role of B-cell receptors for B-cell devel opment and antigen-induced differentiation. F1000Res. 7,429. https:/ / dx.doi.org/ 10.12688\%2Ff1000 research.13567.1

Cite this article as: Hélène Banoun (2021). The role of antibodies in the light of the theory of evolution. A frican Journal of Biological Sciences. 3(3), 1-9. doi: 10.33472/ AFJBS.3.3.2021.1-9. 